\title{
Administrative Reforms of Rural Land in Transition Economies: An Example in China and Vietnam
}

\author{
Nguyen Tan Phat \\ University of Economics \& Law, Vietnam National University HCMC, Ho Chi Minh City, Vietnam \\ Email: ngtaphat@yahoo.com
}

Received August $7^{\text {th }}$, 2012; revised October $5^{\text {th }}, 2012$; accepted October $16^{\text {th }}, 2012$

\begin{abstract}
The administrative issue of rural land has been filled with little concern by the State and scientists but have had a great impact on rural community's life in organization of agricultural production, space for living and the guarantee of rights of land assets of farmers. Moreover, it also has a direct effect on the State's managerial efficiency in rural areas. Vietnam and China have some common points in politics, particularly in policies of farm land and the process of reforms in rural land as well. This article is about China's experience and Vietnam's reality in the economic transition period. Such matters of administrative reforms in rural land in Vietnam and China can be referential lessons for nations with the same circumstances.
\end{abstract}

Keywords: Administrative Reforms; Rural Land; Public Ownership; Private Ownership; Rights of Land Use; Transition Economy

\section{Introduction}

Vietnam and China have some identical issues in politics and economics in the period of economic transition, especially in the rural land with many complicated problems the causes of which have come from land policies. Administrative reforms in rural land have been opening up great opportunities for farmers to get their benefits. However, these reforms have shown some social contradictions among farmers, farmers-local government; farmers-enterprises. This needs more improvement to perfect land laws and democratic process. China had carried out the reforms in land laws before Vietnam, however the ones in Vietnam is more innovative than China. The process of administrative reforms of rural land in China started in 1978, the authorities permitted farmers that: 1) Farmers had a right of land use to purpose of agriculture production according to promise mechanism $^{1}$; and 2) In 2008, the authorities performed a model of liberal transfer in right of land use, but it did a narrow size. Generally, up to now, farmers have not been a right of trade in agriculture land yet.

Vietnam started the process of administrative reforms of rural land in 1981, as the authorities permitted farmers most of rights in land use accepted private property. Farmers were permitted to trade in agriculture land. Thus, agriculture land market has developed since 1993 to led the development of Vietnam agriculture and improve the life of farmers better.

\section{Data and Methodology}

Data: The data of the article is based on: 1) The survey result of land officials in 81 communes in rural areas in 9 provinces in South-east region, Highlands and the Mekong Delta in

\footnotetext{
${ }^{1}$ Promise mechanism is a kind of contract between households with authorities. After paying the contract to authorities, households had a right of land use in the thirty years.
}

Vietnam, which was carried out in a survey of administrative reforms in rural land by the author in January, 2009; and 2) The survey result of 544 farm households in January, 2009. The survey provided 5 main pieces of information:

- The rates of completing the general planning of land

- Granting certificates of right of land use

- Opinions of farmers in organization, management and planning land currently

- Number of land officials

Methodology: The field of research in this article is political economy, especially in the administrative reforms in rural land. I use the method of statistics and description based on: 1) The survey result of land officials in 81 communes in rural areas in 9 provinces in south-east region, highlands and the Mekong Delta in January 2009; 2) The survey result of 544 farm households in January 2009; and 3) The content in land laws, land policies in Vietnam, China during the period of economic transition.

\section{Reforms of Land Mechanism in Reality in China}

Land in China formerly was under public ownership but due to the social-economic growth in recent years, right of private ownership of real estate in which right of land use is also included has been accepted. It means land is the regime of wholepeople ownership and rights of land use have been given to people. China's current law has not asserted the admission of right of private ownership. In city, real estate connects closely with land. It means right of private ownership of a house is admitted but not for that piece of land. In the country, there is its own regime of agricultural laws. Farmers have rights to use or explore for agricultural production based on land-fixed mechanism which is established through a contract between a family household and its commune and district. After the pay 
ment for the contract, farmers will have rights to use exactly with the purpose of agricultural manufacture mentioned before in the contract.

There is a difference between right of using urban land (with the purpose of living) and rural land for living and exploring agriculture.

The administrative division between rural and urban areas indicates the difference of legal organization of land, leading the distinction in freedom of performing that right: urban land has right to be determined (exchange or purchasing) whereas this can't occur in rural areas-there is no right of determination (selling that right of use).

There has recently been a reform in Chinese law allowing to make free decision for fixed-rate farm land. It means transfering is possible if obeying the laws in that province and has been piloting with the permission of central government. In long run, farm land should be transferred freely but with caution as the authority is worried about using rural land for industry, leading to a high risk of losing food security for the country with the population of 1.3 billion.

Urban land is limited about the time of right of land use stipulated by the contract. The State transfers the right of land use to organizations and companies of real estate. According to the Resolution of Chinese Government in 1988, real estate companies pay to the State in just a fixed period of time but not for ever. There are a wide variety of terms depending on the purpose of use. Resolution in 1988 indicates that there is a maximum time of 70 years for land of housing, 50 years for industrial companies, factories and supermarkets and 40 years for tourism land. The detailed speculations are in the decision of giving land. The money of using land is not a sell-buy relation. So, a problem arises that how will it be if the time-limit of giving land is up? Laws in 2007 about rights of properties had a clause of prolonging the land use automatically but failed to define in details so it was considered to be ambiguous and to ease public opinion; besides, there are regulations in detail about under-ground land, land onto the surface and above the surface of that piece of land. To apartments, the explanation for co-owning the basements, corridors is based on the agreement signed in the contract between the customer and the company.

The entire agricultural land is public-owned. In another way, it is possessed by local governments. A majority of farm land in China is community-owned but land with canals, ditches and roads belongs to the State.

\section{Administrative Reforms of Rural Land in Vietnam in Reality: Achievements and Shortcomings}

The heart of the reforms came from the innovation of policies of farm land. First, the Instruction 100 about giving a fixed number of products to labor groups and laborers in agricultural co-operatives ${ }^{2}$. Next, the Resolution 10 about innovation of agri-economic management ${ }^{3}$. And finally the improvement of

\footnotetext{
${ }^{2}$ The content is guiding co-operatives how to give a fixed number of products to family households and laborers; and allows members of the cooperative to invest their capital, strength of labor in the given land and enjoy all products which are fulfilled over criteria.

${ }^{3}$ The main content is giving land back to farmers. It means that farmer households are given farm land and admitted that they are an independent economic unit in production and only submit tax to the State in accordance with the law.
}

land laws ${ }^{4}$ so that a system of land administration can be established to operate the management and organization of farm land production for farmers. Up to the present, there have been nearly 400 legal documents involving the performance of land laws, making this system become massive with numerous new points (Phat \& Dung, 2011).

The administrative system of land includes building up a system of land files with land maps, certificate of land-use right, administrative procedures, machinery and land officers. On nation-wide scale, files of land survey and the certificates have been basically completed for farm land, land for housing in the countryside and land of frequent use for non-agriculture, but the completion reaches about $65 \%$ for forest land and $55 \%$ for living land in cities ${ }^{5}$. At 81 communes in 9 provinces in southeast region, Highlands and the Mekong Delta, the rates of completing general planning of farm land are different. The perfect completion $100 \%$ is $39.51 \%$, between $80 \%$ and $90 \%$ is $33.33 \%$, from $50 \%$ to $70 \%$ is $11.11 \%$, and a rather high rate of $16.05 \%$ has not finished the general planning (Table 1).

According to this survey, $62.2 \%$ of farmland used for growing annual trees has been granted the certificate of right of land use, reaching the level between $90 \%$ - $100 \%$ and $65.2 \%$ for farm land for numerous-year trees (Table 2).

The system of farm land management in rural areas have been innovated but have failed to meet the requirements in life due to the inefficiency of organization and administration in local areas, the shortcomings, and lack of explicitness that cause urgent matters for farmers. There are $75 \%$ of opinions of Northern farmers indicating that planning and land administration are unclear, this rate in highland is $64.71 \%$, central part 53.66\%, south-east region 35.66\% and the Mekong Delta 23.33\% (Table 3).

The lack of explicitness in organization and management of farm land in local areas in Vietnam and China is the root reason causing disagreeableness for farmers, leading to lawsuits, complaints and even social conflicts. The statistics indicates that $80 \%$ of these complaints in Vietnam and China are related to unconvincingly administrative decisions of land of local governments.

\section{Reasons of the Shortcomings}

First, land laws have been improved but unclear in some points. For example, there is still an ambiguity between the right of land ownership and the right of land use. Government wants to maintain supreme right of ownership which belongs to State in the form of entire-people ownership in which the State is the representative of the supreme owner in management and land organization. Whereas in fact, people are given rights by

\footnotetext{
${ }^{4}$ Vietnamese law has amended and added many times: 1987, 1992, 1998, 2001 and 2003 and it is planned to keep on amending in 2012.

${ }^{5}$ According to the report in front of the Parliament of the Minister of Environment and Resources Pham Khoi Nguyen on November 6, 2007, land law has been in valid since 2003, so has the granting of red books. As planned, till the year of 2005, 64 provinces and cities must be completed. This point of time was prolonged till 2006. However, till September 30, 2007, there were only 37 local areas reaching $70 \%$ of the plan. Among them there were 11 provinces and cities finishing $90 \%$ of granting red books and 27 left had half of work incompleted. At some places the red books have finished but people did not get them yet. Some places like Hanoi where there were only $23.8 \%$ of organizations granted red books; Bac Giang $37.08 \%$. The instruction documents of granting red books from 2003 to 2007 were 40 from government to ministries and branches.
} 
Table 1.

The rates of completing the general planning of land in 81 communes in 9 provinces in south-east region, Highlands and the Mekong Delta.

\begin{tabular}{ccccc}
\hline Rates of completion & $100 \%$ & $80 \%-90 \%$ & $50 \%$ - 70\% & Incompleted \\
\hline $\begin{array}{c}\text { Numbers of } \\
\text { communities }\end{array}$ & 32 & 27 & 9 & 13 \\
Rates (\%) & 39.51 & 33.33 & 11.11 & 16.05 \\
\hline
\end{tabular}

Note: Source: Nguyen Tan Phat (2010), The survey result of land officials in 81 communes in rural areas in January, 2009.

Table 2.

Granting certificates of right of land use in communes in 9 provinces in south-east region, highland and the Mekong Delta.

\begin{tabular}{ccccc}
\hline \multirow{2}{*}{$\begin{array}{c}\text { Levels of granting } \\
\text { certificate of } \\
\text { land-use right }\end{array}$} & \multicolumn{2}{c}{ Land for annual trees } & \multicolumn{2}{c}{$\begin{array}{c}\text { Land for } \\
\text { numerous-year trees }\end{array}$} \\
\cline { 2 - 5 } & $\begin{array}{c}\text { Numbers of } \\
\text { communes }\end{array}$ & Rates (\%) & $\begin{array}{c}\text { Numbers of } \\
\text { communes }\end{array}$ & Rates (\%) \\
\hline $90 \%-100 \%$ & 46 & 62.2 & 45 & 65.21 \\
$70 \%-89 \%$ & 18 & 24.3 & 15 & 21.73 \\
$50 \%-69 \%$ & 5 & 6.75 & 5 & 7.24 \\
$<50 \%$ & 5 & 6.75 & 4 & 5.82 \\
\hline
\end{tabular}

Note: Source: Nguyen Tan Phat (2010), The survey result of officials of land survey in 81 communes in rural areas in January, 2009.

Table 3.

Opinions of farmers in organization, management and planning land currently.

\begin{tabular}{cccc}
\hline Parts or regions & Good & Not good, weak & $\begin{array}{c}\text { Still have shortcomings } \\
\text { and unclearness in } \\
\text { planning }\end{array}$ \\
\hline The North & $12.5 \%$ & $29.17 \%$ & $75 \%$ \\
The central part & $34.14 \%$ & $21.95 \%$ & $53.66 \%$ \\
Highland & $21.01 \%$ & $27.73 \%$ & $64.71 \%$ \\
South-east & $45.90 \%$ & $44.54 \%$ & $35.66 \%$ \\
The Mekong Delta & $64.44 \%$ & $28.89 \%$ & $23.33 \%$ \\
\hline
\end{tabular}

Note: Source: Nguyen Tan Phat (2010), The survey result of 544 farm households in January, 2009.

law, which nearly reach the right of ownership. They have a strong desire to possess the perfectly the entire right but failed due to the mechanism of policy. Local governments are given by law the right of management but not be tied down to duties. This is the key point leading to haphazard decisions regardless of public opinion, causing severe conflicts between people and the governments during the past time.

Second, land officials in the local levels (wards and communes) are insufficient in quantity and bad at their quality. So, their performance of policies have difficulties and confusion, leading to the arbitrariness of planning and transferring the purpose of land use, the loose of management, and even giving a hand to speculators, etc., causing disagreement in public and a direct impact on the reasonable benefits of farmers. According to the survey in 81 communes in 9 provinces, the case of merely 1 official in charge of land survey in each commune makes up 71.6\%; a number of communes with 2 officials (it is the official reinforced from the Department of Resources and Environment) is $23.46 \%$; only $2.47 \%$ of with 3 - 4 officials (they are wards next to big urban areas like Thu Duc district and Ho Chi Minh city (Table 4).

In reality, at many communes and wards, the number of officials are just few and work based on their own experience, thus when facing new issues like carrying out compensation, assistance and arrangement of relocation, they show little knowledge of communicative skills and learning people's thoughts and expectation; they solve problems just based on their feelings haphazardly. In another way, they are hardly scientific in resolving new and complicated jobs. This influences on the work's progress and creates passive manners like bureaucracy, causing disagreement leading to complaints and lawsuits of people. So weak are they that they frequently make regrettable mistakes when acting as advisors to superiors about planning, investigation and solving of land disputes.

\section{Referential Solutions to Enhance the Efficiency of Administrative Reforms of Rural Land}

Reforms of agricultural land policy should be comprehensive in all aspects such as law, benefits of State, people and business organizations

1) Rights of ownership and land use must be clear and in the direction of admitting and ensuring rights of property ownership on the farmers' land; 2) Duties and responsibilities of local governments must be speculated in their administrative decisions of land; and administrative conflicts of land between local administration, farmers and enterprises should be solved based on administrative private law. It means that it is necessary to set up administrative courts of land independent with local administration in the aim of bringing impartial decisions; and 3) Duties and benefits of the enterprises involving farm land must be clarified about profits and communal responsibilities.

The work of land officials in local areas must be paid attention to quality and quantity

Their competence plays a key role in performing land policies exactly to what the Government desires, so it is vital that it be improved. They should be provided with knowledge of fixing a price and calculating land tax; launching campaigns of educational propagandas of law; training officials' ways of reconciling and solving disputes unofficially; planning land use and basic concepts of economics.

It is advisable for natural resources and environment offices to have training classes of special topics about compensation, assistance and relocation; topics of merging land or exchanging pieces of land; topics of practical skills of guiding registration procedures and granting certificates of right of land use; topics of planning related to environment and sustainably rural growth, etc.

There should be a scientific calculation of the number of land officials depending on the land surface, the number of households, structure of farm land, land for housing and the forms of work in local areas (Table 5).

Application of high technology should be used to manage rural land

With the high-tech development nowadays, it is essential to apply computer software programs for land administration such as registration of granting certificates of land use, transferring, planning and planning announcement, etc. the information of which must be announced officially in wards or communes. People can access the internet to catch necessary contents so that they could know how much their surface land is, on which 
Table 4.

Number of land officials in 81 communes in 9 provinces in south-east region, highland and the Mekong Delta.

\begin{tabular}{lcccccccc}
\hline $\begin{array}{l}\text { Number of officials } \\
\text { (people)/commune }\end{array}$ & 4 Officials/Commune & Rate (\%) & 3 Officials/Commune & Rate (\%) & 2 Officials/Commune & Rate (\%) & 1 Official/Commune & Rate (\%) \\
\hline
\end{tabular}

Note: Source: Nguyen Tan Phat (2010), The survey result of officials of land survey in 81 communes in rural areas in January, 2009.

Table 5.

Script: Base to calculate the number of land officials in each ward and commune.

\begin{tabular}{|c|c|c|c|c|c|}
\hline Criteria & $\begin{array}{l}\text { Minimum: } 1 \text { land } \\
\text { official/ward or commune }\end{array}$ & $\begin{array}{c}\text { Land surface (ha): } \\
0 \text { for a certain amount of } \\
\text { land; } 1,2,3 \text { or more for } \\
\text { higher rate }\end{array}$ & $\begin{array}{l}\text { Number of people in the } \\
\text { family (total number of } \\
\text { people/ward, commune): } \\
0 \text { for a certain number of } \\
\text { people in the families; } 1,2 \text {, } \\
3 \text { or more for greater rate }\end{array}$ & $\begin{array}{l}\text { Kinds of jobs resolved: } \\
\text { Disputes, land complaints, } \\
\text { land corruption: } 0 \text { for no } \\
\text { problems; } 1,2,3 \text { or more } \\
\text { if there are problems }\end{array}$ & $\begin{array}{c}\text { Total number of land } \\
\text { officials/ward, } \\
\text { commune: } \Sigma\end{array}$ \\
\hline Criteria added & (1) & (2) & (3) & (4) & $\sum=(1)+(2)+(3)+(4)$ \\
\hline
\end{tabular}

Note: Source: Calculated by the author.

location it is on the planning map, which pieces of land is being disputed and how the disputes are going on, etc. All can be restored and gained publicity. It is a good idea for tax submission and registration for confirmation to be computerized. Currently, they can be piloted in local areas with good conditions of qualified land officials and well-equipped machines and then expanded to far-distance areas. So, there will be an informative connection of land between provinces, cities from central authority to local areas. The fact that each piece of land can be encoded with a certain sign will help management and land information become more effective and avoid land speculation. Only type the full name of a certain person, and the present documents of their land will be shown on the computer and indicated clearly how much land they own and where it is or whether he is a kind of person purely buying land for production or just buying to sell it after that.

Supervision and criticism of the performance of land policy should be promoted from the community and non-governmental organizations

1) The roles of media, television have a great effect on ensuring law and benefits of the 2 involved sides; 2) Organizations of protection of human rights and personal dignity should have their own voices to ensure the values of basic rights of people and enterprises; and 3) Communities of farmers and enterprises must do their citizen's duties in performing policy and know how to gain their reasonable benefits by notifying them to state agencies.

\section{Conclusion}

The real of administrative reforms of land in rural areas in
China and Vietnam showed that if improving of effect of administrative reforms of land in rural areas, the authorities have to perfect the land law according to the land private property of farmers and permit people participating real estate market to transfer their agriculture land. Beside that, the staff in the management of land rural areas must be strongly, effectively and having public ethics.

The process of administrative reforms of land in rural areas should connect with the process of developing law, economy and social democracy and require the 2 involved sides to bend over backwards to head for the sustainable growth, improvement of law system, the explicit performance of policy and the guarantee of reasonable benefits for people.

\section{REFERENCES}

Phat, N. T., \& Dung, N. T. (2011). Vietnam's land policy in the transition period. Journal of Tokyo University of Information Sciences, 15, 9-25.

Phat, N. T. (2009). Renovating land management in agriculture in Vietnam: Achievements and problems. Vietnam Economic Review, 184, ISSN: 0868-2984.

Phat, N. T. (2009). Measures to improve the relation of organization and land management in agriculture and rural development in the economic transition period in Vietnam. Economics Studies, 376, ISSN: 0866-7489.

Phat, N. T. (2009). Innovation of land management in agriculture in Vietnam: Achievements and issues. Economics Studies, 374, ISSN: 0866-7489. 